\title{
Characteristics of heavy metals and their evaluation in suspended sediments from Piracicaba river basin (São Paulo, Brazil)
}

\author{
Jefferson Mortatti ${ }^{1}$ \& Jean-Luc Probst ${ }^{2}$
}

\begin{abstract}
Fluxes of the particulate heavy metals like chromium $(\mathrm{Cr})$, copper $(\mathrm{Cu})$, cobalt $(\mathrm{Co})$, nickel $(\mathrm{Ni})$, zinc $(\mathrm{Zn})$ and lead $(\mathrm{Pb})$ were determined along the Piracicaba River basin. Suspended sediments from the main channel and tributaries were sampled during January 2005 (high water period) and analyzed for total concentrations after extraction by alkaline fusion procedure. The average concentrations showed a significant increase pattern from upstream to downstream for $\mathrm{Zn}, \mathrm{Cr}, \mathrm{Ni}, \mathrm{Cu}$ and $\mathrm{Pb}$, except for $\mathrm{Co}$, in which only a small variation was noted. The specific fluxes of $\mathrm{Zn}, \mathrm{Cr}$ and $\mathrm{Ni}$ were slightly higher $\left(79.9,33.3\right.$ and $20 \mathrm{~kg} \mathrm{~km}^{-2} \mathrm{yr}^{-1}$, respectively) in comparison to other industrialized regions in Asia, Europe, North and South America. Significative correlations between organic matter and $\mathrm{Cr}, \mathrm{Cu}$ and $\mathrm{Co}$, observed in the suspended sediments along the Piracicaba River basin, revealed that heavy metals were adsorbed or complexed by the organic matter, while $\mathrm{Ni}$ and $\mathrm{Pb}$ were significatively correlated with Fe oxide. The geo-accumulation index $\left(I_{\text {geo }}\right)$ used to evaluate the pollution degree of the Piracicaba River sediments, revealed a medium to strong pollution for $\mathrm{Zn}$ in the entire basin and moderate pollution for $\mathrm{Cr}$ and $\mathrm{Ni}$ at downstream direction around an important area covered by sugar cane plantations and urban areas influenced by domestic sewage.
\end{abstract}

Keywords: riverine transport, heavy metal, Piracicaba River, suspended sediment, geo-accumulation index.

Resumo Características dos metais pesados e sua avaliação nos sedimentos em suspensão da bacia de drenagem do rio Piracicaba (São Paulo, Brasil). Foram determinados os transportes dos metais pesados cromo $(\mathrm{Cr})$, cobre $(\mathrm{Cu})$, cobalto $(\mathrm{Co})$, níquel $(\mathrm{Ni})$, zinco $(\mathrm{Zn})$ e chumbo $(\mathrm{Pb})$ nos sedimentos em suspensão ao longo da bacia do rio Piracicaba. Os sedimentos foram amostrados na calha principal dos rios estudados durante o período de cheia (Janeiro de 2005) e analisados após abertura total das amostras pelo processo da fusão alcalina. As concentrações médias obtidas ao longo da bacia do rio Piracicaba apresentaram um padrão de aumento significativo das nascentes até a foz para $\mathrm{Zn}, \mathrm{Cr}, \mathrm{Ni}, \mathrm{Cu}$ e $\mathrm{Pb}$, exceto para o $\mathrm{Co}$, que pouco variou ao longo da bacia. Os transportes sólidos específicos de $\mathrm{Zn}$, Cr e $\mathrm{N}$ nos sedimentos estudados foram relativamente altos $\left(79,9,33,3\right.$ e $20 \mathrm{~kg} \mathrm{~km}^{-2} \mathrm{a}^{-1}$, respectivamente) em comparação com outras regiões industrializadas da Ásia, Europa, América do Norte e América do Sul. Correlações lineares significativas puderam ser observadas entre as concentrações da matéria orgânica e $\mathrm{Cr}, \mathrm{Cu}$ e Co nos sedimentos em suspensão, evidenciando a complexação desses metais na fase orgânica, enquanto que $\mathrm{Ni}$ e $\mathrm{Pb}$ se mostraram correlacionados com a fração dos óxidos de Fe. O índice de geoacumulação $\left(I_{\text {geo }}\right)$ usado para a avaliação das classes e do grau de poluição dos metais pesados presentes na carga sólida da bacia do rio Piracicaba evidenciou uma poluição de média à forte para $\mathrm{Zn}$ em toda a bacia e uma poluição moderada para $\mathrm{Cr}$ e Ni em direção à foz, no entorno da zona agriculturável com cana-de-açúcar e sob influencia urbana.

Palavras-chave: transporte fluvial, metais pesados, Rio Piracicaba, sedimentos, índice de geoacumulação.

INTRODUCTION Heavy metals are present in various environmental compartments (atmosphere, water, soil, sediments and living organisms) and these forms are controlled by physical and chemical conditions as well as by biological processes. The toxicity of some heavy metals in fluvial ecosystems is related not only to the observed high concentrations but also with the weathering process. In this way, several data focus on heavy metal concentrations in dissolved and particulate river loads (Elderfield et al. 1990; Goldstein \& Jacobsen 1988; Sholkovitz 1992). However, river suspended matters, consist of two major phases: the residual and labile fractions. According to Leleyter \& Probst (1999) met- als from labile fractions are participating in liquid-solid adsorption-desorption, surface reaction and co-precipitation with different solid fractions such as clay minerals, carbonates, oxides and organic matter. Thus, the study in order to quantify the major trace elements partitioned between labile and residual fractions in fluvial sediments is very important for local and regional settings.

Fluvial transport estimates of particulate heavy metals along the drainage basin are usually based on metal concentrations measurements on the sediment loads. However, it provides inadequate information about the potential toxicity of these chemical species when the natural background of major heavy metals is 
not considered (Kersten \& Forstner 1995). The degree of particulate heavy metal pollution can be evaluated in terms of the element geochemical background value in a drainage area, normally obtained in the headwater region without anthropogenic influences, according to Salomons \& Forstner (1984) using an geo-accumulation index (Müller 1979; Yan et al. 2007; Audry et al. 2004; Simonovski et al. 2003).

This study aimed to estimate the fluvial transport of particulate heavy metals along the Piracicaba River basin (a medium-scale watershed in southeast Brazil under anthropogenic influences). Intensity quantification of the metal pollution occurring in the particulate load during a high water period, specifying characteristics, distributions and heavy metal sources of in the suspended sediments along the Piracicaba River basin, allowed an assessment of the factors controlling bioavailability of these chemical species in river waters and sediments.

STUDY AREA The Piracicaba River basin is located in a subtropical climate zone ranged from $45^{\circ} 51^{\prime}$ to $48^{\circ} 24^{\prime} \mathrm{W}$ and a latitudinal extent ranging from $22^{\circ} 05^{\prime}$ to $23^{\circ} 16^{\prime} \mathrm{S}$ draining an area of $12,400 \mathrm{~km}^{2}$. The Piracicaba River is formed by the confluence of Atibaia and Jaguari rivers flowing from east to west receiving the Corumbataí River waters after cross the urban area of Piracicaba city (Fig. 1).

According to Krusche et al. (1997) the upper part to the center of the basin is occupied by degraded forest and pasture, while the other part is supplied by sugarcane culture. This region contains about $61 \mathrm{mu}-$ nicipal districts with over $3,000,000$ inhabitants where only $10 \%$ of the urban sewage is treated. The total load of the urban sewage generated along the basin was calculated to be 120 t B.O.D. (biochemical oxygen demand) per day (Favaro et al. 2004).

The eastern headwaters of Piracicaba River basin are relatively unpolluted, whereas the central and western sub-basins, which have higher population densities, are polluted mainly for having domestic effluents and industrial discharges into the river. In this catchment, two major rock types are outcropping: crystalline rock, in the upper part of the basin, and, carbonate sedimentary rock in the lower part of the basin. The weathering profiles are mainly represented by red lateritic soils that are composed of kaolinite and iron oxides.

METHODOLOGY The suspended sediments were sampled during January 2005 (flood period), along Piracicaba River basin, in the sampling stations: Atibaia River (P1A and P2A), Jaguari River (P1J and P2J), Piracicaba River (P1P and P2P) and Corumbataí River (P1C). The river water, at $2 \mathrm{~m}$ depth, was pumped into polyethylene bottles $(30 \mathrm{~L})$ and let to decant the particulate phase in the laboratory. After a calcination period at $1000^{\circ} \mathrm{C}$ in order to eliminate organic matter, $100 \mathrm{mg}$ of fine sediment $(<63 \mu \mathrm{m})$, was carried out to alkaline fusion procedure with lithium tetraborate and lithium metaborate $(2: 1)$ in a platinum crucible under $1000{ }^{\circ} \mathrm{C}$ during 30 minutes. The residual phase was taken in $100 \mathrm{~mL} \mathrm{HNO}{ }_{3} 2 \mathrm{~N}$.

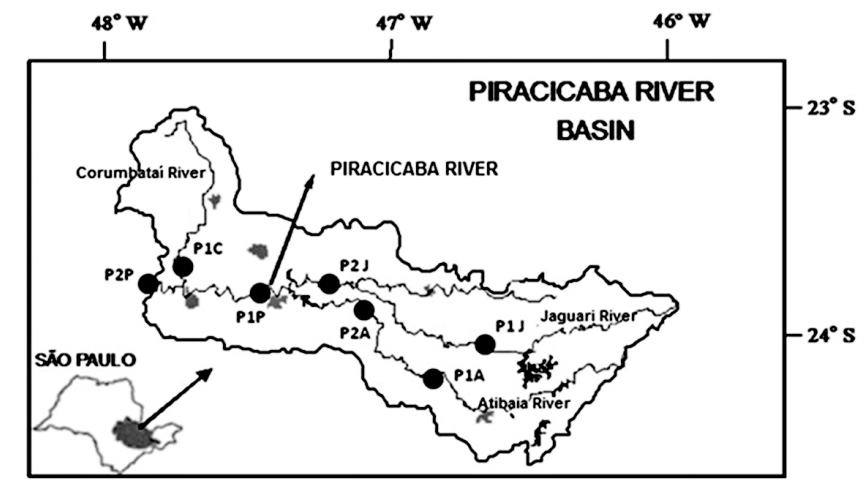

Figure 1 - Location of the Piracicaba River basin including the sampling stations along the river and main tributaries.

In order to determine the amount of fine suspended sediment, a single stage sampler was used at $2 \mathrm{~m}$ depth. About $300 \mathrm{~mL}$ of river water were filtered, dried at $60{ }^{\circ} \mathrm{C}$ and weighed again. The organic matter content was calculated after particulate organic carbon determination (1.72 POC) directly in tin capsule using an ANCA-SL mass spectrometer coupled with a gas chromatography.

All chemical analyses were performed using an Inductively Coupled Plasma Atomic Emission Spectrometry (ICP-AES). Samples were analyzed in triplicate, including the reactive blank. The accuracy of the heavy metal analysis was performed using Soil7 (IAEA reference standard). Percentages of recovery were as follows: $\mathrm{Cr}(92.3 \%), \mathrm{Cu}(94.1 \%), \mathrm{Co}(95.3 \%)$, $\mathrm{Ni}$ (97.4\%), Zn (103\%) and $\mathrm{Pb}(107.1 \%)$.

\section{RESULTS AND DISCUSSION}

Chemical Characteristics Suspended sediments from the upper part of the basin, mainly for Atibaia River (P1A) and Jaguari River (P1J), exhibited a combined silt and clay fractions of more than $75 \%$, while at downstream sampling stations the suspended sediments were classified as sandy ( $>60 \%$ sand).

The low $\mathrm{SiO}_{2}$ concentrations verified in the upper part of the basin for P1A and P1J, 35.1 and $37.0 \%$ respectively, with an increasing of $\mathrm{Al}_{2} \mathrm{O}_{3}(27.2$ and $26.6 \%$, respectively), are in agreement to the granulometric observations (Tab. 1). The suspended sediments for all sampling stations present in average, very low base cation content $\left(\mathrm{CaO}+\mathrm{MgO}+\mathrm{Na}_{2} \mathrm{O}+\mathrm{K}_{2} \mathrm{O}<4\right)$ and high chemical maturity index of about 10.4, calculated according to the equation (1) defined by Konta (1985) as follows:

$\mathrm{ChM}=\mathrm{Al}_{2} \mathrm{O}_{3}(\%) /\left(\mathrm{Na}_{2} \mathrm{O}+\mathrm{MgO}+\mathrm{CaO}\right)(\%)$

The elevated ChM index verified in the suspended sediment is associated to the high rock weathering process occurring in Piracicaba River basin. High concentrations of $\mathrm{Fe}$ and $\mathrm{Mn}$ oxides confirm the predominance of lateritic soils in the drainage basin. 
Particulate Heavy Metal Transport Fine suspended sediment contents (FSS) along Piracicaba river basin were ranged from 35.4 and $19.2 \mathrm{mg} \mathrm{L}^{-1}$ from upper ba$\sin \left(\mathrm{P} 1 \mathrm{~A}\right.$ and P1J) to $172.5 \mathrm{mg} \mathrm{L}^{-1}$ near the mouth (P2P). This behavior was associated with the runoff increase along the basin, 47 to $376 \mathrm{~m}^{3} \mathrm{~s}^{-1}$, giving a spatial variation in the particulate load of about $190 \mathrm{t} \mathrm{km}^{-2} \mathrm{y}^{-1}$ (Tab. 2 ). The specific load carried out by the Piracicaba River at mouth (P2P) during the high water period $\left(190 \mathrm{t} \mathrm{km}^{-2}\right.$ $\left.\mathrm{y}^{-1}\right)$ could be classified as high transport according to the classification proposed by Meybeck et al. (2003) based on global variability of daily total suspended solids and their fluxes in rivers ( 73 to $365 \mathrm{t} \mathrm{km}^{-2} \mathrm{y}^{-1}$ ). This behavior could be justified by agricultural practices associated to sugarcane plantations along the year over the basin, which increase the soil remobilization to streams.

The specific transports estimated for the particulate heavy metals were calculated considering the instantaneous discharge and the influence drainage area for each sampling point. The observed particulate heavy metal specific transports were relatively high at downstream direction, with important $\mathrm{Zn}, \mathrm{Cr}, \mathrm{Ni}$ and $\mathrm{Cu}$ contributions (79.86, 33.27, 19.96 and $18.63 \mathrm{~kg} \mathrm{~km}^{-2} \mathrm{yr}^{-1}$, respectively.
At upper basin, high specific transport of $\mathrm{Zn}\left(6.65 \mathrm{~kg} \mathrm{~km}^{-2}\right.$ $\mathrm{yr}^{-1}$ ) was observed mainly for Atibaia River (P1A). When compared with other world rivers, the observed specific transports for $\mathrm{Zn}, \mathrm{Cr}$, Ni and $\mathrm{Cu}$ were higher than Mississippi, St. Lawrence, Rhone and Madeira rivers (Guyot 1993; Zhang \& Liu 2002; Radakovitch et al. 2008).

Correlation Analysis The correlation coefficient matrix between heavy metals in the suspended sediments of Piracicaba River basin is presented in table 3.

It can be observed that all particulate heavy metals were positively correlated with each other and most correlations were statistically significant $(p<0.01)$ showing similar geochemical features, except for the relations between $\mathrm{Co}-\mathrm{Ni}, \mathrm{Co}-\mathrm{Zn}$ and $\mathrm{Pb}-\mathrm{Zn}$.

Positive correlations between organic matter and $\mathrm{Cr}, \mathrm{Cu}$ and $\mathrm{Co}$ were observed in the suspended sediments along Piracicaba River basin, which indicates that these metals are associated with the organic matter. According to Kabata-Pendias \& Pendias (1991), Gaiero et al. (1997) and Leleyter \& Probst (1999) the metals associated with the labile organic fraction could be degraded under oxidizing conditions on aquatic sedi-

Table 1 - Distribution of major elements in the suspended sediments along Piracicaba River basin during January 2005 (flood period).

\begin{tabular}{ccccccccccccc}
\hline $\begin{array}{c}\text { Sampling } \\
\text { site }\end{array}$ & $\mathrm{OM}$ & $\mathrm{SiO}_{2}$ & $\mathrm{Al}_{2} \mathrm{O}_{3}$ & $\mathrm{MgO}$ & $\mathrm{CaO}$ & $\begin{array}{c}\mathrm{Fe}_{2} \mathrm{O}_{3} \\
(\%)\end{array}$ & $\begin{array}{c}\mathrm{Mn}_{3} \mathrm{O}_{4} \\
\mathrm{TiO}_{2}\end{array}$ & $\mathrm{Na}_{2} \mathrm{O}$ & $\mathrm{K}_{2} \mathrm{O}$ & $\mathrm{P}_{2} \mathrm{O}_{5}$ \\
\hline P1A & 8.83 & 35.10 & 27.20 & 0.57 & 0.76 & 7.90 & 0.32 & 1.20 & 0.40 & 1.41 & 0.47 \\
P2A & 10.00 & 45.80 & 25.20 & 0.75 & 0.45 & 8.00 & 0.15 & 1.05 & 0.30 & 2.30 & 0.40 \\
P1J & 9.45 & 37.00 & 26.60 & 0.75 & 1.00 & 6.30 & 0.36 & 1.28 & 0.49 & 1.50 & 0.62 \\
P2J & 7.50 & 46.90 & 24.90 & 0.85 & 0.80 & 7.20 & 0.15 & 1.00 & 0.42 & 1.99 & 0.26 \\
P1P & 9.15 & 50.30 & 19.04 & 0.90 & 0.79 & 8.20 & 0.23 & 1.25 & 0.60 & 1.60 & 0.25 \\
P1C & 7.20 & 65.30 & 8.50 & 1.28 & 0.85 & 8.20 & 0.21 & 1.30 & 0.40 & 1.56 & 0.20 \\
P2P & 10.70 & 60.50 & 17.28 & 0.77 & 0.55 & 8.90 & 0.20 & 1.17 & 0.35 & 1.40 & 0.32 \\
\hline
\end{tabular}

Table 2 - Content and transport of suspended sediments (FSS and TsS) and heavy metals, including organic matter concentration (OM) along Piracicaba River basin during January 2005 (high water period).

\begin{tabular}{|c|c|c|c|c|c|c|c|c|c|c|c|c|c|c|c|c|c|}
\hline \multirow{3}{*}{$\begin{array}{c}\text { Sampling } \\
\text { Site } \\
\mathrm{P} 1 \mathrm{~A}\end{array}$} & \multirow{2}{*}{\begin{tabular}{|c|} 
Basin \\
Area \\
$\mathrm{km}^{2}$ \\
\end{tabular}} & \multirow{2}{*}{\begin{tabular}{|c|} 
Runoff \\
$\mathrm{m}^{3} \mathrm{~s}^{-1}$ \\
\end{tabular}} & \multirow{2}{*}{$\begin{array}{c}\mathrm{OM} \\
\%\end{array}$} & \multirow{2}{*}{$\begin{array}{l}\text { FSS } \\
\text { mg L- }\end{array}$} & \multirow{2}{*}{$\begin{array}{c}T_{F S S} \\
t_{k m^{2}} y^{-1} \\
\end{array}$} & \multicolumn{2}{|l|}{$\mathrm{Cr}$} & \multicolumn{2}{|c|}{$\mathrm{Cu}$} & \multicolumn{2}{|c|}{ Co } & \multicolumn{2}{|c|}{$\mathrm{Ni}$} & \multicolumn{2}{|l|}{$\mathrm{Zn}$} & \multicolumn{2}{|c|}{$\mathrm{Pb}$} \\
\hline & & & & & & $\mu \mathrm{g} \mathrm{g}^{-1} \mathrm{~kg}$ & $\mathrm{~km}^{-2} \mathrm{y}^{-1}$ & $\mu \mathrm{g} \mathrm{g}^{-1}$ & $\mathrm{~km}^{-2} \mathrm{y}^{-1}$ & $\mu \mathrm{g} \mathrm{g}^{-1}$ & $\mathrm{~kg} \mathrm{~km}^{-2} \mathrm{y}^{-1}$ & $\mu \mathrm{g} \mathrm{g}^{-1} \mathrm{k}$ & $\mathrm{kg} \mathrm{km}^{-2} \mathrm{y}^{-1}$ & $\mu \mathrm{g} \mathrm{g}^{-1} \mathrm{~kg} \mathrm{k}$ & $\mathrm{cm}^{-2} \mathrm{y}^{-1}$ & $\mu \mathrm{g} \mathrm{g}^{-1} \mathrm{~kg}$ & $m^{-2} y^{-1}$ \\
\hline & 1813 & 47 & 8.8 & 35.4 & 28.7 & $143 \pm 8$ & 4.1 & $70 \pm 5$ & 2.0 & $23 \pm 1$ & 0.7 & $62 \pm 3$ & 0.7 & $230 \pm 9$ & 6.7 & $35 \pm 2$ & 1.0 \\
\hline $\mathrm{P} 2 \mathrm{~A}$ & 2621 & 68 & 10.0 & 125.6 & 102.6 & $165 \pm 11$ & 17.0 & $85 \pm 5$ & 8.7 & $30 \pm 3$ & 3.1 & $70 \pm 4$ & 7.2 & $250 \pm 14$ & 25.7 & $40 \pm 3$ & 4.1 \\
\hline $\mathrm{P} 1 \mathrm{~J}$ & 1931 & 52 & 9.5 & 19.2 & 16.1 & $115 \pm 9$ & 1.9 & $50 \pm 2$ & 0.8 & $12 \pm 1$ & 0.2 & $41 \pm 2$ & 0.7 & $210 \pm 15$ & 3.4 & $14 \pm 1$ & 0.2 \\
\hline $\mathrm{P} 2 \mathrm{~J}$ & 3380 & 161 & 7.5 & 108.6 & 163.0 & $120 \pm 9$ & 19.6 & $60 \pm 4$ & 9.8 & $12 \pm 1$ & 2.0 & $50 \pm 1$ & 8.2 & $240 \pm 12$ & 39.2 & $18 \pm 2$ & 2.9 \\
\hline P1P & 8626 & 304 & 9.2 & 100.0 & 111.2 & $153 \pm 6$ & 11.1 & $95 \pm 7$ & 6.9 & $19 \pm 2$ & 1.4 & $90 \pm 6$ & 6.5 & $390 \pm 18$ & 28.2 & $45 \pm 3$ & 3.3 \\
\hline $\mathrm{P} 1 \mathrm{C}$ & 1627 & 70 & 7.2 & 99.3 & 134.6 & $120 \pm 8$ & 16.2 & $80 \pm 5$ & 10.8 & $20 \pm 1$ & 2.7 & $85 \pm 6$ & 11.5 & $180 \pm 12$ & 24.3 & $42 \pm 4$ & 5.7 \\
\hline $\mathrm{P} 2 \mathrm{P}$ & 10758 & 376 & 10.7 & 172.5 & 190.1 & $175 \pm 15$ & 33.3 & $98 \pm 7$ & 18.7 & $25 \pm 1$ & 4.8 & $105 \pm 5$ & 20.0 & $420 \pm 15$ & 79.9 & $50 \pm 3$ & 9.5 \\
\hline
\end{tabular}


Table 3 - Correlation coefficient matrix between the major heavy metals in the suspended sediments along Piracicaba River basin during January 2005 (high water period).

\begin{tabular}{ccccccccc}
\hline $\begin{array}{c}\text { Correlation } \\
\text { coefficient }\end{array}$ & $\mathrm{Cr}$ & $\mathrm{Cu}$ & $\mathrm{Co}$ & $\mathrm{Ni}$ & $\mathrm{Zn}$ & $\mathrm{Pb}$ & $\begin{array}{c}\mathrm{Fe} \\
\text { oxide }\end{array}$ & $\begin{array}{c}\text { Organic } \\
\text { matter }\end{array}$ \\
\hline $\mathrm{Cr}$ & 1 & & & & & & & \\
$\mathrm{Cu}$ & 0.843 & 1 & & & & & & \\
$\mathrm{Co}$ & 0.840 & 0.704 & 1 & & & & & \\
$\mathrm{Ni}$ & 0.691 & 0.950 & 0.575 & 1 & & & & \\
$\mathrm{Zn}$ & 0.756 & 0.737 & 0.279 & 0.702 & 1 & & & \\
$\mathrm{~Pb}$ & 0.765 & 0.963 & 0.770 & 0.948 & 0.586 & 1 & & \\
Fe oxide & 0.753 & 0.930 & 0.729 & 0.935 & 0.596 & 0.960 & 1 & \\
Organic & & & & & & \\
matter & 0.977 & 0.879 & 0.875 & 0.782 & 0.693 & 0.855 & 0.861 & 1 \\
\hline
\end{tabular}

ments, causing the release of soluble metals.

$\mathrm{Cu}, \mathrm{Ni}$ and $\mathrm{Pb}$ were positively correlated with Fe oxide. The metals associated with this fraction could be mobilized under anoxic conditions on aquatic sediments (Tessier \& Campbell 1987).

The results obtained by the inter-element correlations about common metal sources in suspended sediments along the Piracicaba River basin are in accordance with the previous results verified in the same river basin, using sequential extraction procedure of fine sediments. Considering the $\mathrm{Pb}$, about $90 \%$ was linked with $\mathrm{Fe}$ oxide, while for Co only $40 \%$ shown to be related with this fraction. In terms of bioavailability, $40 \%$ of the $\mathrm{Pb}$ was in non-residual phase, while for $\mathrm{Co}$ this value was about $60 \%$.

Intensity of Heavy Metal Pollution The geo-accumulation index was used to evaluate the degree of heavy metal pollution in the suspended sediments along the Piracicaba River basin during the high water period. The geo-accumulation index $\left(I_{\text {geo }}\right)$ introduced by Müller (1979) is shown as follows (equation 2):

$$
I_{\text {geo }}=\log _{2}[\mathrm{Me}]_{\text {sed }} / 1.5[\mathrm{Me}]_{\text {background }}
$$

where $[\mathrm{Me}]_{\text {sed }}$ is the concentration of a given heavy metal and $[\mathrm{Me}]_{\text {background }}$ is the geochemical background value of the element in the reference site.

The index $I_{\text {geo }}$ is associated with a qualitative scale of pollution intensity and is divided into 7 degrees ( 0 to 6 ) which reflects the conditions ranging from zero pollution to very strong pollution.

The geochemical background values for the studied heavy metals were obtained from the riverbed sediments of Piracicaba River at the upper part of the basin by Falótico (2001) and Favaro et al. (2004). The mean background concentrations used to calculate the geo-accumulation index for $\mathrm{Cr}, \mathrm{Cu}, \mathrm{Co}, \mathrm{Ni}, \mathrm{Zn}$ and $\mathrm{Pb}$ were $40,50,7,28,50$ and $30 \mu \mathrm{g} \mathrm{g}^{-1}$, respectively.

According to the calculated $I_{\mathrm{geo}}$, along of Piracicaba river basin and main tributaries (Tab. 4), there were no large differences for the sampling stations located at the upper part of the basin (P1A, Atibaia River and P1J, Jaguari River), corresponding to none pollution for $\mathrm{Cu}$ and $\mathrm{Pb}$, none to medium pollution for $\mathrm{Ni}$ and medium pollution for $\mathrm{Cr}$ and $\mathrm{Zn}$. Downstream, at the main channel of Piracicaba River (P2P) the pollution degree seems to be more serious, with medium to strong pollution for $\mathrm{Zn}$ and medium pollution for $\mathrm{Cr}, \mathrm{Co}$ and $\mathrm{Ni}$.

CONCLUSION The results of medium to strong heavy metal pollution along Piracicaba River basin, observed in terms of the high metal transport, correlation analysis and geo-accumulation index, could be severely detrimental to aquatic biota with the sediment remobilization occurrences during flood events, oxidizing particulate heavy metals from the labile fraction of the sediment. Other activities related to the agricultural practices could increase the mechanical erosion along the basin elevating the transport of the suspended sediment in the basin. The domestic untreated sewage released to the riv-

Table 4 - Geo-accumulation index $\left(I_{\text {ged }}\right)$ and pollution degree along Piracicaba River basin during January 2005 (flood period).

\begin{tabular}{ccccccc|cc}
\hline $\begin{array}{c}\text { Sampling } \\
\text { site }\end{array}$ & $\mathrm{Cr}$ & $\mathrm{Cu}$ & $\mathrm{Co}$ & $\mathrm{Ni}$ & $\mathrm{Zn}$ & $\mathrm{Pb}$ & Degree of pollution \\
\hline $\mathrm{P} 1 \mathrm{~A}$ & $1-2$ & $<0$ & $1-2$ & $0-1$ & $1-2$ & $<0$ & $<0$ & none \\
$\mathrm{P} 2 \mathrm{~A}$ & $1-2$ & $0-1$ & $1-2$ & $0-1$ & $1-2$ & $<0$ & $>0-1$ & none to medium \\
P1J & $0-1$ & $<0$ & $0-1$ & $<0$ & $1-2$ & $<0$ & $>1-2$ & medium \\
P2J & $1-2$ & $<0$ & $0-1$ & $0-1$ & $1-2$ & $<0$ & $>2-3$ & medium to strong \\
P1P & $1-2$ & $0-1$ & $0-1$ & $1-2$ & $2-3$ & $0-1$ & $>3-4$ & strong \\
P1C & $1-2$ & $0-1$ & $0-1$ & $1-2$ & $0-1$ & $<0$ & $>4-5$ & strong to very strong \\
P2P & $1-2$ & $0-1$ & $1-2$ & $1-2$ & $2-3$ & $0-1$ & $>5$ & very strong \\
\hline
\end{tabular}


er water increases the degraded organic matter causing anoxic conditions in depth, changing the oxy-reduction conditions in the sediment labile fractions. The observed severe heavy metal pollution indicates that the studied catchment is affected by anthropogenic activities, which contribute to the input of particulate metals increasing concentrations above background levels.

The results of this scientific investigation can be helpful to understand the behavior of the heavy metals and their relationships with the labile fraction of the fluvial sediments in order to control possible toxicity occurrences.

Acknowledgments This work was supported by Fundação de Amparo a Pesquisa do Estado de São Paulo, FAPESP, and by USP-COFECUB International Cooperation Program between Centro de Energia Nuclear na Agricultura, CENA/USP, São Paulo, Brazil, and Laboratoire de Mécanismes de Transfert em Géologie, UMR 5563, CNRS, Universite Paul Sabatier, Toulouse, France.

\section{Referências}

Audry S., Schafer J., Blanc G., Jouanneau J. M. 2004. Fifty-year sedimentary record of heavy metal pollution $(\mathrm{Cd}, \mathrm{Zn}, \mathrm{Cu}, \mathrm{Pb})$ in the Lot River reservoirs (France). Environm. Pollution, 132:413-426.

Elderfield H., Upstill-Goddard R., Sholkovitz E.R. 1990. The rare earth elements in rivers, estuaries and coastal seas and their significance to the composition of ocean water. Geochim. et Cosmochim. Acta, 54:971-991.

Falótico M.H.B. 2001. Distribuição das concentrações de metais pesados em água, matéria em suspensão e sedimento de fundo na bacia do rio Piracicaba. PhD Thesis, Universidade de São Paulo, Brazil, 92 p.

Favaro P.C., Fernandes E.A.N., Ferraz E.S.B., Falótico M.H.B. 2004. Time still to restore the polluted Piracicaba river basin. J. Radioanal. Nucl. Chem., 2:217-221.

Gaiero D.M., Ross G.R., Depetris P.J., Kempe S. 1997. Spatial and temporal variability of total non residual heavy metals content in stream sediments from the Suquia River system, Cordoba, Argentina, Water Air Soil Pollut, 93:303-319.

Goldstein S.J. \& Jacobsen S.B. 1988. Rare earth elements in rivers waters, Earth Planet Sci Lett; ; 89:35-47.

Guyot J.L. 1992. Hydrogéochimie des fleuves de l'Amazonie bolivienne. $\mathrm{PhD}$ Thesis, Université de Bordeaux, France, $362 \mathrm{p}$.

Kabata-Pendias A. \& Pendias H. 1991. Trace elements in soils and plants. $2^{\text {nd }}$ ed. London, CRC Press, $365 \mathrm{p}$.

Kersten M. \& Forstner U. 1995. Speciation of trace metals in sediments and combustion waste. In: Ure A.M., Davidson C.M. (eds.) Chemical Speciation in the Environment. London: Blackie Academic and Professional, p. 234-275.

Konta J. 1985. Mineralogy and chemical maturity of suspended matter in major world rivers sampled under the Scope/Unep projet. In: Degens E.T. (ed.) Transport of carbon and minerals in major world rivers. Part 3, 58, Mitt. Geol. Palaont, Inst. Univ. Hamburg, Scope/Unep Sonderband, p. 569-592.

Krusche A.V., Carvalho F.P., Moraes J.M., Ballester M.V.R., Hornink S., Martinelli L.A., Victoria R.L. 1997. Spatial and temporal water quality variability in the Piracicaba river basin, Brazil. J. Am. Water Res. Assoc., 33:11171123.

Leleyter L. \& Probst J.L. 1999. A new sequential extraction procedure for the speciation of particulate trace elements in river sediments. Intern. J. Environ. Anal. Chem., 73(2):109-128.

Meybeck M., Laroche L., Durr H.H., Syvitski J.P.M. 2003. Global variability of daily total suspended solids and their fluxes in rivers. Global. Planet. Change, 39:6593.

Müller G. 1979. Schwermetalle in den sedimenten des rheins-veränderungen seit. Umschav, 79:133-149.

Radakovitch O., Roussiez V., Ollivier P., Ludwig W., Grenz C., Probst J.L. 2008. Input of particulate heavy metals from rivers and associated sedimentary deposits on the Gulf of Lion continental shelf. Estuar. Costal Shelf Sci., 77:285-295.

Salomons W. \& Forstner U. 1984. Metals in the hydrocycle. Berlin, Springer-Verlag, $349 \mathrm{p}$.

Sholkovitz E.R. 1992. Chemical evolution of rare earth elements: fractionation between colloidal and solution phases of filtered river water. Earth Planet. Sci. Lett., 114:77-84.

Simonovski J., Owens C., Birch G. 2003. Heavy metals in sediments of the upper Hawkesbury-Nepean river. Austral Geograph. Studies, 41(2):196-207.

Tessie A. \& Campbell P.G.C. 1987. Partitioning of trace metals in sediments: relationship with bioavailability. Hydrobiology, 149:43-52.

Yan J.P., Yong H., Huang H. 2007. Characteristics of heavy metals and their evaluation in sediments from middle and lower reaches of the Huaihe river. J. China Univ. Mining Techn., 17(3):414-417.

Zhang J., Liu C.L. 2002. Riverine composition and estuarine geochemistry of particulate metals in China: weathering features, anthropogenic impact and chemical fluxes. Estuar. Coast Shelf Sci., 54:1051-1070.

Manuscrito ID 16230 Submetido em 03 de dezembro de 2009 Aceito em 15 de fevereiro de 2010 